\title{
ASSESSMENT OF ACCESS TO AND USE OF PRIMARY CARE IN THE QUILOMBOLA COMMUNITY OF ANANINDEUA-PARÁ-BRAZIL
}

\section{${ }^{*}$ Lidiane Assunção de Vasconcelos, ${ }^{2}$ Marcos Valério Santos da Silva, ${ }^{2}$ Marcieni Ataíde Andrade, ${ }^{3}$ Camilo Eduardo Almeida Pereira, ${ }^{4}$ Zélia de Oliveira Saldanha, ${ }^{5}$ Ana Júlia Cunha Brito, ${ }^{6}$ Anderson Roberto Assunção de Vasconcelos and 7Simone Daria Assunção Vasconcelos Galdino}

${ }^{1}$ Master in Health, Environment and Society in the Amazon, Federal University of Pará - UFPA. Teacher at the Faculty Cosmopolitan. Belém-PA. Brazil

${ }^{2}$ PhD in Pharmaceutical Sciences, Federal University of Pará - UFPA. Teacher of the Institute of Health Sciences - UFPA. Belém-PA. Brazil

${ }^{3}$ Master in Health, Environment and Society in the Amazon, Federal University of Pará - UFPA. Teacher of the Faculty of Medicine -UFPA. Belém-PA. Brazil

${ }^{4}$ Master in Nursing, State University of Pará - UEPA. Specialist in Oncological Nursing. Teacher at the Faculty Cosmopolitan. Belém-PA. Brazil

${ }^{5}$ Master in Development and Urban Environment, University of the Amazon - UNAMA. Teacher at the Faculty Cosmopolitan. Belém-PA. Brazil

${ }^{6}$ Academic of System of Information, Federal University of Pará - UFPA. Belém-PA. Brazil

${ }^{7}$ Master in Management and Planning in Health Services by the Santa Casa of Mercy of Pará Foundation - FSCMP. BelémPA. Brazil

\section{ARTICLE INFO}

\section{Article History:}

Received $13^{\text {th }}$ August, 2019

Received in revised form

$26^{\text {th }}$ September, 2019

Accepted $08^{\text {th }}$ October, 2019

Published online $30^{\text {th }}$ November, 2019

\section{Key Words:}

Primary health care.

Evaluation Quilombola communities.

Family health strategy.

*Corresponding author:

Lidiane Assunção de Vasconcelos

\begin{abstract}
Objective: Evaluation of the use and accessibility of the Family Health Strategy using PCATool for the adult population of a quilombola community. Method: A descriptive cross-sectional, quantitative study had the participation of 92 residents of the Quilombola Community of Abacatal, older than 30 years, in the period from April 2015 to June 2015. For data collection, we used the Instrument for Primary Care Evaluation (PCATool) adult version, which consists of 87 items divided into ten components related to the attributes of Primary Health Care (PHC), for the study three dimensions were used: Degree of affiliation; Degree of use; Degree of accessibility. Results: It was shown that the majority of residents resort to the Family Health Strategy (FHS) when they become ill or need advice about their health; and some declared using other services, negatively assessing the attribute use. As for the availability of services, care and communication with the FHS, the answers were mostly negative. Conclusion: It was evidenced that there is no community recognition of the local FHS as its gateway, as it is not considered resolutive, and the study contributed in the sense that, when assessing it, it is indicated occasionally where it is necessary to move towards the achievement of comprehensive and quality care.
\end{abstract}

Copyright (C) 2019, Lidiane Assunção de Vasconcelos et al. This is an open access article distributed under the Creative Commons Attribution License, which permits unrestricted use, distribution, and reproduction in any medium, provided the original work is properly cited.

Citation: Lidiane Assunção de Vasconcelos, Marcos Valério Santos da Silva, Marcieni Ataíde Andrade et al. 2019. "Assessment of access to and use of primary care in the quilombola community of ananindeua-pará-Brazil”, International Journal of Development Research, 09, (11), 31369-31374.

\section{INTRODUCTION}

The communities or populations of the quilombos, are characterized by all the descendent members of individuals who participated in the constitution of the agro-rural territories in the periods of the slavery system and sequentially, also after the formal abolition of slavery with the respective validity of the Golden Law (ALMEIDA, 2010). According to Leite (2010), the communities of blacks in rural regions historically bring narratives of conflicts, which come from the first Republic. According to the author these reports of insurgent groups were registered in articles of the Federal Constitution of 1988, especially those dealing with essential rights to life, recognition and protection of historical and cultural heritage and territorial rights. Where the "quilombola" right that the Brazilian Constitution aims to achieve is the right over the place, the right not only to land or to conditions of production, but above all its recognition in the legal order which is, above 
all, a human rights policy. This population group has guaranteed access to public policies made available by the federal government, through the National Policy for the Promotion of Racial Equality (NPPRE), which mainly seeks to reduce racial inequalities in Brazil, with emphasis on the black population. This is a policy structured through the following social-political instruments: International Convention on the Elimination of all forms of Discrimination; Brazil without Racism and the Durban Action Plan (BRASIL, 2012). This action is included in the Brazil Quilombola Program (BQP), and is based on four main axes: access to land; infrastructure and quality of life; local development and productive inclusion; rights and citizenship (BRASIL, 2012). Currently there are 2.197 officially recognized communities in the Brazilian State, of these, 2.040 communities are certified by the Palmares Cultural Foundation (PCF), being 63\% of them in the Northeast, only 157 are certified, but they are not certified. Of the total, 1.229 processes are open for the titling of lands in the National Institute of Colonization and Agrarian Reform (INCRA) and 207 communities were titled, benefiting 12.906 families. (BRASIL, 2013). There are 214,000 quilombola families in Brazil and 1.17 million quilombolas. According to the socioeconomic aspects identified from the 80,000 quilombola families registered in the Unified (CADUNICO) Registry, there are 214,000 quilombola families in Brazil and 1.17 million quilombolas, which is responsible for the registration of low-income families, it was found that, predominantly, they declared themselves black or brown, are beneficiaries of the BolsaFamília Program, are in extreme poverty, develop agriculture, extractivism or artisanal fishing activities and $24.81 \%$ do not know how to read (BRASIL, 2013), a worrying figure, since the national average of illiterate people is 9\% (IBGE, 2011).

It was instituted, in 2009, through Ordinance No. $992 \backslash 2009$, of the Ministry of Health, the national policy of Integral health of the black population whose objective is "to promote the integral health of the black population, prioritizing the reduction of ethnic-racial inequalities, the Combating racism and discrimination in SUS institutions and services ". It also includes in its specific objectives "the access of the black population of the field and the forest, in particular the quilombolas populations, the actions and the health services" demarcating the insertion of the Quilombola movement in the discussions on the topic of health, a fact that During the decade of 90 was dissociated, expressing a mostly urban character of health claims by the black movement (BRASIL, 2013). In this context, Primary Health Care is determined as the first level of care within the health system, evidenced by the presence of four essential attributes (access in the first contact with the health system, longitudinality, comprehensive care and coordination of care within the system) and three derived attributes (family orientation, community orientation and cultural competence), principles that comprise the total dimension of Primary Care. (STARFIELD, 2012). The insertion of Primary Health Care occurred in 1991, after the creation of the SUS, when the Ministry of Health $(\mathrm{MH})$ the Community Health Agent Program (CHAP). The objective was to reduce the indicators of maternal and infant morbidity and mortality in the Northeast region of the country. With the success of CHAP, the MH created, in 1994, the Family Health Program (FHP), which soon became known as a strategy to change the model of health care in Brazil, seeking to provoke reflections and transformations in institutions, thought patterns and behavior of Brazilian professionals and citizens (PAIM, 2009). These changes sought to launch a new look at health care, in view of integral practices and that sought to see the individual not as a pathology, but as a social being. From this perspective, we emphasize the importance of primary health care as an essential strategy to organize health services, in order to enable universal access to services and integral and integrated care over time. According to Leão et al (2011), it is possible that better results from the PHC services will be achieved from the knowledge and operationalization of its ordering principles. For these authors, the experiences have shown that the health systems that are organized from a primary care, structured in accordance with their essential and derivative attributes, are more effective and of higher quality. It is also verified that the proposals aimed at Quilombolas communities cannot account for the real social, biological, economic and cultural needs of this group.

Being viewed, often, practices of the hegemonic model that continue to influence the work of workers and managers of the health system, 14 immobilizing, thus, the population itself in the search for autonomy and participation in issues related to Health. Therefore, it is observed that the quality of the care provided ends up not meeting the needs of the group highlighted, setting itself as another instrument that is not able to respond to the desires of the population and the professionals who are part of this dynamic. Therefore, strengthen the quality of practices to the possibility of evaluating the actions developed with the Primary Health Care, specifically the care offered to the quilombola population. It is known that evaluation is an instrument that can provide the apprehension of the limiting and potentiating aspects of daily activities and, consequently, can cooperate with the reorientation of health practices. Given the various health needs presented in the services, and their organizational and care characteristics, it is essential to evaluate the care process in the health care of quilombola populations, highlighting the presence and extension of the essential attribute access to the first PHC contact, and also the advances and limits present in the care to this outstanding audience. Thus, the objective is to assess the use and accessibility of the Family Health Strategy using PCATool for the adult population of a quilombola community.

\section{MATERIALS AND METHODS}

This is a descriptive, cross-sectional research, with a quantitative approach, conducted in a Quilombola Abacatal Community in Ananindeua, PA, from April 2015 to June 2015, with 92 community residents. In which were included in the survey: age equal to or older than 30 years; reside in the territory belonging to the quilombola community at least one year, and who agree to participate freely in the survey. The data collection instrument consisted of the application of the Primary Care Assessment Tool (PCATool-Brasil) proposed by the Ministry of Health, composed of blocks of questions corresponding to the attributes of Primary Health Care (Access, Longitudinality, Integrity, Coordination, Family Orientation, Community Orientation) and three initial questions that measure the degree of affiliation to the health service. (BRASIL, 2010). The PCATool adult version consists of 87 items divided into ten components related to the 
attributes of Primary Health Care (PHC). Three dimensions were used in the study: degree of affiliation ( 5 items), first contact access - use (3 items), first contact access accessibility (12 items) as per (BRASIL, 2010). Data collection was carried out in two visits to the community by the researcher, through the project Socio-ecological and Biological Determinant of Obesity, Diabetes and Arterial Hypertension in Afro-descendant Populations of the Amazon: Seeking concrete answers to the ontogeny of complex diseases, whose objective is to identify the main ecological and biological social causes related to the emergence of obesity, arterial hypertension, diabetes and pathologies associated with these among quilombolas, and their immediate consequences in individuals and in local health services. The individuals who participated in the study were only those who accepted the project's invitation to participate in the collection of laboratory tests. The collection occurred during the waiting room for collection of laboratory tests.

Initially, the responsible researcher introduced herself and explained the objectives of the study, verifying the availability of 38 people to participate in the research following with the application of the adult version of PCATool-Brazil. Then, to ensure the right choice of the scores for the answers, the interviewees were informed about the 5 alternative answers $(1=$ certainly not, $2=$ probably not, $3=$ probably yes, $3=$ probably yes, $4=$ certainly yes, $9=$ don't know/not remember) before applying the questionnaire. The analysis of the data collected from the participants took place according to the recommendation of the PCATool organizers. The instrument guides that, for the data analysis, the inversion of items $\mathrm{C} 2$, $\mathrm{C} 4, \mathrm{C} 5$ and D10 occurs, since these items were formulated in such a way that the higher the value assigned, the lower the orientation to PHC. That is, these items should have their values inverted to: value $4=1$, value $3=2$, value $2=3$ and value $1=4$ (BRASIL, 2010). The comparison between participants and non-participants used the chi-square (gender) and $\mathrm{t}$ Student tests for independent samples (mean age), the level of significance was 5\%. Simple frequencies were performed for the answers double use and accessibility. For data analysis, the SPSS Statistics, version 21.0 software was used. The project was approved by the Research Ethics Committee of the Institute of Health Sciences/UFPA according to CAAE opinion 499-920 and meets Resolution 466/2012. All participants received a verbal and written explanation of the Free and Informed Consent Form on the objective of the study, procedures to be performed, risks and benefits of participation and subsequent signing of this document at the time of the approach.

\section{RESULTS}

We analyzed each element that compose the dimensions of first contact, these being considered from the answers to each of the questions, and not from a synthetic value of all of the same dimension. This allowed us to visualize the different aspects involved in the exercise of integrality and the perception of the user of PHC services. In the questioning about the first contact (utilization), it is noted that the percentages of negative responses (low score) are higher in all three questions that compose the dimension of use, but with statistical significance only in question B2 $(\mathrm{P}$-value $=0.0322)$, as shown in table 1 , below.
Table 1. Number and Proportion (\%) of users who answered, according to scores, to the questionnaire questions in the categories of first contact (use)

\begin{tabular}{cccccc}
\hline \multirow{2}{*}{ Use } & \multicolumn{3}{c}{$\leq 6,6$ (Low score) } & \multicolumn{3}{c}{$\geq 6,6$ (High Score) } & \multirow{2}{*}{ P-value ${ }^{(1)}$} \\
\cline { 2 - 5 } & $\mathrm{N}$ & $\%$ & $\mathrm{~N}$ & $\%$ & \\
\hline B1 & 38 & 60,32 & 25 & 39,68 & $0,1015^{(2)}$ \\
& & 63,49 & & & \\
B2 & 40 & 23 & 36,51 & $0,0322 *$ & \\
B3 & 32 & 50,79 & 31 & 49,21 & 0,8997 \\
\hline
\end{tabular}

(2) At the significance level of 0.10 Source: Research protocol, (2016).

Regarding the Accessibility dimension, Table 2 shows that most of the questions that make up this dimension obtained higher percentages of negative answers $(\leq 6,6$ (Low Score) for users of PHC services ( $\mathrm{p}$-value $<0.05$ ). Item C8 (p-value $>0.05$ ) with $57.14 \%$ (36) of negative answers and $34.92 \%(22)$ of users with positive answers showed no significant difference at the level of $5 \%$

Table 5. Number and Proportion (\%) of users who answered, according to scores, to the questions of the questionnaire in the categories of first contact (accessibility)

\begin{tabular}{llllll}
\hline \multirow{2}{*}{ Accessibility } & \multicolumn{2}{l}{$<, 6$ (Low score) } & \multicolumn{2}{l}{$\geq 6,6$ (High Score) } & \multirow{2}{*}{ P-value ${ }^{(1)}$} \\
\cline { 2 - 5 } & $\mathrm{N}$ & $\%$ & $\mathrm{~N}$ & $\%$ & \\
\hline C1 & 55 & 87,30 & 6 & 9,52 & $<0,0001^{*}$ \\
C2 & 56 & 88,89 & 4 & 6,35 & $<0,0001^{*}$ \\
C3 & 46 & 73,02 & 17 & 26,98 & $0,0003^{*}$ \\
C4 & 57 & 90,48 & 3 & 4,76 & $<0,0001^{*}$ \\
C5 & 51 & 80,95 & 5 & 7,94 & $<0,0001^{*}$ \\
C6 & 48 & 76,19 & 10 & 15,87 & $<0,0001^{*}$ \\
C7 & 58 & 92,06 & 3 & 4,76 & $<0,0001^{*}$ \\
C8 & 36 & 57,14 & 22 & 34,92 & $0,0660^{(1)}$ \\
C9 & 59 & 93,65 & 3 & 4,76 & $<0,0001^{*}$ \\
C10 & 48 & 76,19 & 15 & 23,81 & $<0,0001^{*}$ \\
C11 & 56 & 88,89 & 7 & 11,11 & $<0,0001^{*}$ \\
C12 & 51 & 80,95 & 12 & 19,05 & $<0,0001^{*}$ \\
\hline
\end{tabular}

(1) Chi-squared test for proportions. * Significant at 0.05 level.

(1) At the significance level of 0.10. Source: Research Protocol,(2016).

Regarding the scores calculated from the evaluation, it is noted in Table 3 that the dimension of "utilization" presented a higher mean score $(\mu=2.23)$ than the mean score of the dimension "accessibility" $(\mu=1.81)$ and this difference between the means was significant at the level of $5 \%$ (p-value $<0.05)$.

Table 3. Average scores regarding the categories of first contact and accessibility of users to PHC services

\begin{tabular}{llll}
\hline \multirow{2}{*}{ Dimensions of PHC } & \multicolumn{2}{l}{ Scores } & P-value \\
\cline { 2 - 3 } & Average & DP & \\
Use & 2,23 & 0,75 & $0,0000 *$ \\
Accessibility & 1,81 & 1,59 & \\
(1) T test (for equality of averages). * & Significant at 0.05 level. \\
. Source: Research Protocol (2016). & &
\end{tabular}

Table 4 shows that the evaluation of each of the items that compose the dimensions "utilization" and "accessibility" showed that the accessibility dimension received a lower mean score, $(\mathrm{M}=2.70)$ than the mean score of the use dimension $(\mathrm{M}$ $=4.11$ ). When evaluating the items of each dimension in isolation and considering that the possible responses for each of the items were: "Sure yes" (value =4), "Probably yes" (value = 3), "Probably not" (value = 2), "Certainly not" (value $=1$ ) we found that In the Use dimension, item B2 received the lowest score (3.70). 
Table 4. Average scores regarding the categories of first contact and accessibility of users to PHC services

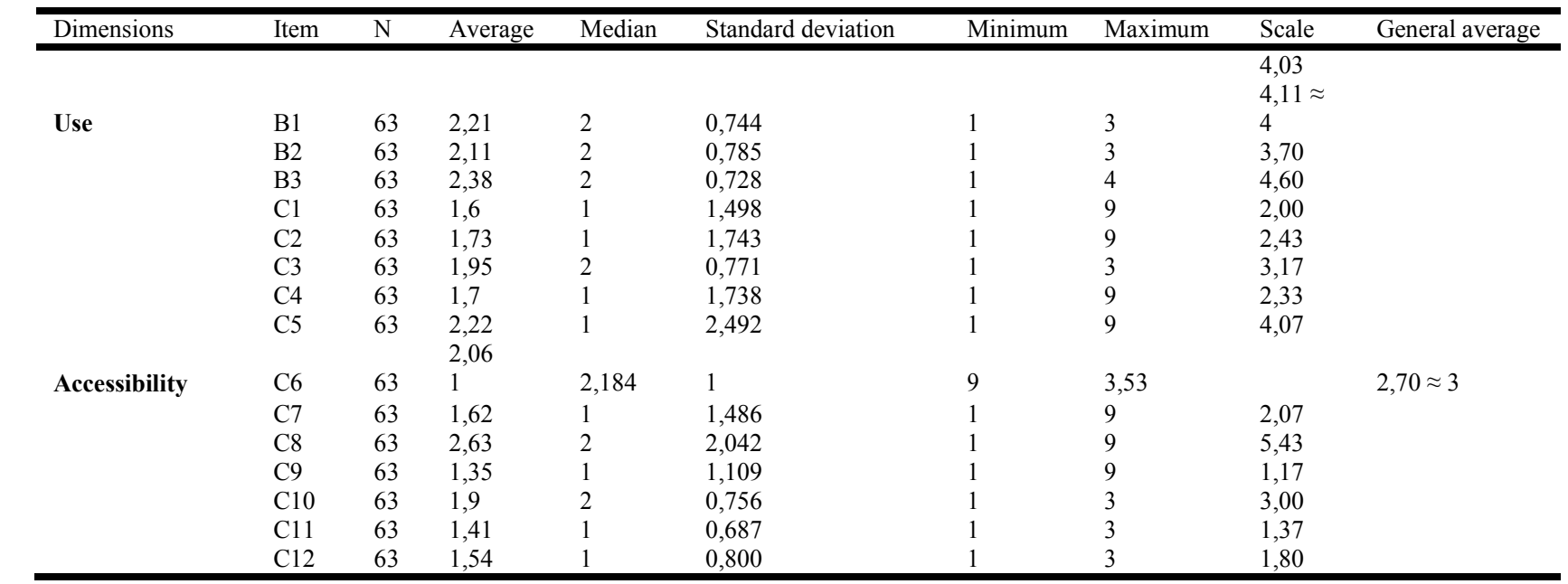

Source: Research Protocol, (2016).

Table 5. Frequency and percentage of users of PHC services, by gender

\begin{tabular}{llll}
\hline Genre & Frequency & Percentage (\%) & Accumulated percentage (\%) \\
\hline Male & 21 & 33,30 & 33,30 \\
Female & 42 & 66,70 & 100,00 \\
Total & 63 & 100,00 & - \\
\hline
\end{tabular}

Source: Research Protocol, (2016).

Table 6. Frequency and percentage of users of PHC services, by degree of affiliation

\begin{tabular}{llll}
\hline Degree of affiliation & Frequency & Percentage (\%) & Accumulated percentage (\%) \\
\hline 1 & 11 & 17,46 & 17,46 \\
2 & 30 & 47,62 & 65,08 \\
3 & 7 & 11,11 & 76,19 \\
4 & 15 & 23,81 & 100,00 \\
Total & 63 & 100,00 & - \\
\hline
\end{tabular}

Table 7. Frequency and percentage of users of PHC services, by score

\begin{tabular}{|c|c|c|c|c|c|c|c|c|c|c|c|c|c|c|c|}
\hline \multirow[t]{2}{*}{ Dimension } & \multirow[t]{2}{*}{ Items } & \multicolumn{3}{|c|}{1} & 2 & \multicolumn{2}{|c|}{$\begin{array}{l}\text { Total Low } \\
\text { Score }\end{array}$} & \multicolumn{3}{|c|}{3} & 4 & \multicolumn{2}{|c|}{$\begin{array}{l}\text { Total High } \\
\text { Score }\end{array}$} & \multicolumn{2}{|c|}{$\begin{array}{l}9 \text { (Do not } \\
\text { know) }\end{array}$} \\
\hline & & Qtd & $\%$ & Qtd & $\%$ & Qtd & $\%$ & Qtd & $\%$ & Qtd & $\%$ & Qtd & $\%$ & Qtd & $\%$ \\
\hline & B1 & 12 & 19,05 & 26 & 41,27 & 38 & 60,32 & 25 & 39,68 & 0 & 0,00 & 25 & 39,68 & 0 & 0,00 \\
\hline \multirow[t]{7}{*}{ Use } & B2 & 16 & 25,40 & 24 & 38,10 & 40 & 63,49 & 23 & 36,51 & 0 & 0,00 & 23 & 36,51 & 0 & 0,00 \\
\hline & B3 & 8 & 12,70 & 24 & 38,10 & 32 & 50,79 & 30 & 47,62 & 0 & 0,00 & 30 & 47,62 & 0 & 0,00 \\
\hline & $\mathrm{C} 1$ & 45 & 71,43 & 10 & 15,87 & 55 & 87,30 & 6 & 9,52 & 0 & 0,00 & 6 & 9,52 & 2 & 3,17 \\
\hline & $\mathrm{C} 2$ & 42 & 66,67 & 14 & 22,22 & 56 & 88,89 & 4 & 6,35 & 0 & 0,00 & 4 & 6,35 & 3 & 4,76 \\
\hline & C3 & 20 & 31,75 & 26 & 41,27 & 46 & 73,02 & 17 & 26,98 & 0 & 0,00 & 17 & 26,98 & 0 & 0,00 \\
\hline & $\mathrm{C} 4$ & 43 & 68,25 & 14 & 22,22 & 57 & 90,48 & 3 & 4,76 & 0 & 0,00 & 3 & 4,76 & 3 & 4,76 \\
\hline & C5 & 40 & 63,49 & 11 & 17,46 & 51 & 80,95 & 5 & 7,94 & 0 & 0,00 & 5 & 7,94 & 7 & $\begin{array}{l}11,1 \\
1\end{array}$ \\
\hline \multirow[t]{7}{*}{ Accessibility } & C6 & 41 & 65,08 & 7 & 11,11 & 48 & 76,19 & 10 & 15,87 & 0 & 0,00 & 10 & 15,87 & 5 & 7,94 \\
\hline & $\mathrm{C} 7$ & 42 & 66,67 & 16 & 25,40 & 58 & 92,06 & 2 & 3,17 & 1 & 1,59 & 3 & 4,76 & 2 & 3,17 \\
\hline & $\mathrm{C} 8$ & 17 & 26,98 & 19 & 30,16 & 36 & 57,14 & 22 & 34,92 & 0 & 0,00 & 22 & 34,92 & 5 & 7,94 \\
\hline & C9 & 51 & 80,95 & 8 & 12,70 & 59 & 93,65 & 3 & 4,76 & 0 & 0,00 & 3 & 4,76 & 1 & 1,59 \\
\hline & $\mathrm{C} 10$ & 21 & 33,33 & 27 & 42,86 & 48 & 76,19 & 15 & 23,81 & 0 & 0,00 & 15 & 23,81 & 0 & 0,00 \\
\hline & $\mathrm{C} 11$ & 44 & 69,84 & 12 & 19,05 & 56 & 88,89 & 7 & 11,11 & 0 & 0,00 & 7 & 11,11 & 0 & 0,00 \\
\hline & $\mathrm{C} 12$ & 41 & 65,08 & 10 & 15,87 & 51 & 80,95 & 12 & 19,05 & 0 & 0,00 & 12 & 19,05 & 0 & 0,00 \\
\hline
\end{tabular}

Note: "Sure yes" (value = 4), "Probably yes" (value = 3), "Probably not" (value = 2), "Certainly not" (value = 1).

Source: Research Protocol, (2016).

In the accessibility dimension, it is verified that item C9 received the lowest score (1.17) and the item $\mathrm{C} 8$ received the highest mean score (5.43). Most users of PHC services are female $(66.70 \%-42)$. It was verified that $47.62 \%$ (30) of the users had a degree 2 affiliation. Since grades 1 and 2 make up $65.08 \%$ of users, as shown in Table 8 . When assessing the frequency of users according to the answers (scores). It is verified that in all the items the answers were concentrated in scores 1 and 2, with percentages B1 (60.32\%-38 users), B2 (63.49\%-40 users) and B3 (50.79\%-32 users). In the accessibility dimension, the percentages of scores 1 and 2 were also higher, but when the percentages were compared, it was verified that all exceeded $70 \%$ of the answers, except for item C8 (57.14\%-36 users).

\section{DISCUSSION}

The evaluation of the quality of health services through the PCA Tool instrument, validated by MH (BRAZIL, 2010), allowed us to observe that the degree of affiliation was one of the dimensions best evaluated by the users, which allows inferring that this group identifies the FHS as a referral service for health care, showing a strong link between users and health 
services. This data corroborates the study conducted by Leão, Caldeira and Oliveira (2011), who, when assessing the attributes of PHC in child health care in the city of Montes Claros/MG, also using PCATool, identified that $77.7 \%$ of caregivers have $\mathrm{PHC}$ as Reference. With regard to $\mathrm{PHC}$ services, we found that the Quilombola Community of Abacatal receives coverage from a Family Health Strategy Unit of Aurá (FHS Aurá) that is part of the Sanitary Pole I, located on Rodovia BR 316, Estrada do Aurá s/n. composed of two Family Health Teams (FHS JardimJaponês and FHS Aurá). The FHS JardimJaponês is the team that covers the territory belonging to the quilombola Abacatal community. According to the National Registry of Health Establishment, the team is composed of: 1 nurse, 1 doctor, 1 dentist surgeon, 1 nursing assistant, 1 oral health assistant and 5 community health workers. When evaluating the first contact access attribute, the Utilization component, which is the component that is directly linked to the relationship to which the professional is sought in case of routine consultations, the search for services in case of a new adverse health event as well as referral for consultation with a specialist, the study demonstrates that the percentages of negative answers (low score) are higher in all three questions that comprise the dimension of use, which indicates that the users of the quilombola community evaluate the use as bad what differs from the results Reis (2013) where in his study the Composite Index of the Use of Services was considered good and was better evaluated than the accessibility. It is worth mentioning that the use of the services is fully correlated with the attitude of the user, however, is motivated by characteristics of the service, since it can facilitate or prevent the user to perceive it as accessible.

The Accessibility component, of this same attribute, obtained mean scores in the three strata below 6.6, showing weak presence and extension of this attribute component. In their studies Oliveira, 2011; Marques et al., 2014 this component also presented unsatisfactory scores, which according to these authors points to the existence of difficulties in meeting the needs, such as lack of care on the same day and delay in scheduling a routine appointment, aspects highlighted in the instrument. Kovacs et al. (2005) shows that Accessibility, as one of the structural elements of the PHC, when not effective, can negatively impact on the functioning of the service and, thus, intervene in the performance of other attributes. The items of this component propose the evaluation of how much the PHC health service is available to the user, its capacity for routine care, spontaneous demand, an acute disease or acute chronic disease. Where most of the questions that make up this dimension obtained higher percentages of negative answers ( $\leq 6,6$ (Low Score) for users of PHC services). The item C9 that indicates users when arriving at the health service has either wait more than 30 minutes to consult with the doctor or nurse without counting screening or reception received the lowest score (1.17). The demonstration shows that adult users of the quilombola community in Abacatal wait more than thirty minutes to receive the scheduled care, which was also mentioned by users of other works (SILVA el tal 2013) where it is stated that the users interviewed wait more than 30 minutes for the medical consultation. This result indicates poor quality in the planning of the service of the PHC of the quilombola community studied, because the "waiting time" is adopted as a parameter to measure the barrier of organizational accessibility (STARFIELD, 2002) and exceeding the limit of thirty minutes implies commitment in the performance of the service. (PEREIRA et al 2011). Item C8 received the highest average score (5.43). This item refers to whether it is easy to make an appointment for a review consultation in the service of the quilombola community studied. What we can not say with a good evaluation, because this score even if it has a higher value, the others are still below the scores that according to Starfield (2002) are considered high, that is above 6.6. But even so, this result may reflect aspects that facilitate the access of users in the health facilities referred by the interviewees, such as the scheduling of some appointments by community health agents and the "no need to sleep in line" to schedule appointments.

Items $\mathrm{C} 1, \mathrm{C} 2, \mathrm{C} 4$ to $\mathrm{C} 7$ analyzed how the care is structured (days of the week of attendance to the public, hours of operation, forms and the agility of communication with the service, existence of the possibility of care by professionals of that Service when it is not in operation) most of the questions presented higher percentages of scores 1 and 2 . These findings corroborate the study by Reis et al (2013), where they report the unavailability of care by the FHS or by professionals connected to the service during weekends and after $6 \mathrm{pm}$, as well as the absence of counseling or scheduling mechanisms by telephone during the normal hours of operation of the FHS or when the service is closed, concluding that the accessibility of the service studied is not adequate. Because according to Sarsfield (2002) accessibility is only considered adequacy when the supply and demand of services and includes availability, convenience or delay in obtaining a consultation, the inadequacy of schedules and the type of scheduling, as well as no need for payment, waiting time for consultation and other procedures. In this study it was noted that the dimension of "use" had a higher mean score $(\mu=2.23)$ than the mean score of the dimension "accessibility" $(\mu=1.81)$ these results are equivalent to the results of Lima (2015) where the dimension accessibility obtained the lowest mean (1.80). Much of the reference score in this study $(\leq 6,6)$. Results that according to the author are opposed to Benazzi's (2010) where accessibility was better evaluated, both by professionals and by users (approximately $50 \%$ of the total), according to the maximum possible points of the instrument for this dimension. These results only demonstrate that the health service of the community studied has serious problems in welcoming its users. According to Silva (2009), the reception is a fundamental part in the accessibility of users to health services, being one of the main tools for the humanization of services and care provided by these offered. For this author a good reception, resoluteness, listening to the user, meeting their needs and the completeness of care are key elements in this process.

\section{Conclusion}

This research demonstrates that this population has not received assistance recommended by the SUS principles. It is necessary interventions in the management process of these services that provide assistance to these populations, with improvement of infrastructure, reorganization of actions and training of health professionals. When considering some limitations, one of them is the lack of national studies on the subject, especially among quilombola populations in the northern region of Brazil, we point to the need for new similar 
evaluations. The fact that the evaluation portrays the perception of a single community may also represent a limiting factor to the generalization of the data. However, it should be noted that the same socioeconomic reality and the same history of segregation and abandonment are present in many communities in the north and northeast of the country, which gives rise, minimally, to a deeper reflection on issues of access to health and equity for such communities. It should also be noted that the perception recorded did not include all social actors, and the perspectives of managers and service providers should also be known, for a better confrontation of the situation. Thus, the study points out the need to conduct new research capturing the vision of health professionals and managers. Consequently, the study was able to certify the importance of evaluating the PHC attributes from the perspective of the user, mainly by the practical applicability of the instrument used in conducting it, representing an important tool for improving the quality of health services. It contributes in the sense that, when evaluating, it is indicated punctually where it is necessary to advance towards the achievement of comprehensive and quality care. Based on these findings, it is also necessary for the military to establish policies, to materialize them.

\section{REFERENCES}

ALMEIDA, A.W.B. Territórios quilombolas e conflitos: cadernos de debates Nova Cartografia Social. Manaus: Projeto Nova Cartografia Social da Amazônia/ UEAEdições, 2010.

ARAÚJO, Lavínia Uchôa Azevedo et al. Avaliação da qualidade da atenção primária à saúde sob a perspectiva do idoso Revista Ciência \& Saúde Coletiva, v.19, n.8, p.3521-3532, 2012.

BATISTA, L. E.;ESCUDER, M.M.L.;PEREIRA, J.C.R. A cor da morte: causas de óbito segundo características de raça no Estado de São Paulo, 1999 a 2001. Rev. Saúde Pública,v. 38, n. 5, p.630-636, 2004.

Disponível em: <http://189.28.128.100/dab/docs/ publicacoes/ geral/pnab.pdf>. Acesso em: 15 dez. 2015.

INSTITUTO Brasileiro de Geografia e Estatística (IBGE). Estados@Pará. Disponível em: <http://ibge.gov.br/ estadosat/perfil.php?sigla=pa>. Acesso em: 16 nov. 2015.

LEÃO, C.D.A, CALDEIRA, A.P. Avaliação da Associação entre qualificação de médicos e enfermeiros em atenção primária à saúde e qualidade da atenção. Ciência e Saúde Coletiva, v. 16 , p. 4415-23,2011.

LEITE, I.B. Humanidades Insurgentes: Conflitos e Criminalização dos Quilombos. Caderno de Debates Nova Cartografia Social: Territórios Quilombolas e Conflitos. v.1, n.2, 2010.

LOPES, F.; WERNECK, J. P. BATISTA, L. E. (Org.). Saúde da População Negra. Rio de Janeiro: DP et alii, 2012, p. 249263.

MARQUES, A. S. et al. População quilombola no norte de Minas Gerais: invisibilidade, desigualdades e negação de acesso ao sistema público de saúde. Boletim do Instituto de Saúde, v.12, n.2, p. 154-161, 2010.

MENDES, Eugênio Vilaça. As redes de atenção à saúde. Brasília: Organização Pan- Americana da Saúde. Conselho Nacional de Secretários de Saúde. 2. ed, 2011. Disponível em:<http://apsredes.org/site2012/wp-content/ uploads/2012/03/Redes-de-Atencao-mendes2.pdf $>$. Acesso em: 11 dez. 2015.
Ministério da Saúde. Secretaria de Atenção à Saúde. Departamento de Atenção Básica. Política nacional de Atenção Básica. Brasília: Ministério da Saúde, 2012.

Ministério da Saúde. Secretaria de Atenção à Saúde. Departamento de Atenção Básica. Manual do Instrumento de Avaliação da Atenção Primária à Saúde - Primary Care Assessment Tool - Brasil. Brasília, DF, 2010. Disponível: $<$ http://www.rededepesquisaaps.org.br/UserFiles/ File/Manual_PCATool_VF.pdf $>$. Acesso em: $11 \mathrm{dez} .2015$.

Ministério da Saúde. Secretaria de Atenção em Saúde. Departamento de Atenção Básica. Manual do instrumento de avaliação da atenção primária à saúde: primary care assessment tool Pcatool - Brasil. Brasília: Ministério da Saúde, 2010. Disponível em: <http://bvsms.saude.gov.br/ bvs/publicacoes/manual_avaliacao_pcatool_brasil.pdf $>$. Acesso em: $11 \mathrm{dez} .201 \overline{5}$.

OLIVEIRA E SILVA CS et al. Integralidade e Atenção Primária à Saúde: avaliação sob a ótica dos usuários Ciência \& Saúde Coletiva, v.19, n.11, p. 4407-4415, 2014.

OLIVEIRA, Beatriz Rosana Gonçalves de et al. Acesso e utilização dos serviços na Estratégia Saúde da Família na perspectiva dos gestores, profissionais e usuários. Ciência Saúde Coletiva.v.18, n.11, p.3321-31, 2013.

PAIM, Jairnilson Silva. O que é SUS. Rio de Janeiro: Fiocruz, 2009.

RINEHART, D. Política Nacional de Saúde Integral da População Negra: discursos da gestão municipal do SUS. Dissertação. (Programa de pós-Graduação em Ciências da Saúde da Universidade de Brasília), 2013.

SÁ, M.S. Estudos de corte transversal. UFBA, 2007. Disponível $\mathrm{em}:<$ http://www.ceargs.org.br/port/aulas/ novas/Marcia_EstudosTransversais_12julho9h. Ppt $>$. Acesso em: 09 dez. 2015 .

Secretaria de Políticas de Promoção da Igualdade Racial. Guia de Políticas Públicas para Comunidades Quilombolas. Disponível em: <http:// www.seppir.gov.br/arquivospdf/guia-pbq>. Acesso em: 12maio 2015.

SILVA, M.J.G.; LIMA, F.S.S.; HAMANN, E.M. Uso dos Serviços Públicos de Saúde para DST/HIV/AIDS por Comunidades Remanescentes de Quilombos no Brasil. Saúde Soc, v.19, n.2, p.109-120, 2010.

SILVA, Z.P.S. et al. Perfil sociodemográfico e padrão de utilização dos serviços de saúde do Sistema Único de Saúde (SUS), 2003- 2008. Ciênc. Saúde Coletiva, v.16, n.9, p.38073816, 2011.

SOUZA, E. H. A. et al. Raça e o uso dos serviços de saúde bucal por idosos. Ciênc. e Saúde Coletiva,v.17, n.8, p. 2063-2070, 2012.

STARFIELD, B.; SHI, L.; MACINKO, J. Contribution of primary care to health systems and health. Milbank Q, v. 83, n.3, p. 457-502, 2005.

STARFIELD, Barbara. Atenção primária: equilíbrio entre necessidades de saúde, serviços e tecnologia. Brasília: UNESCO/Ministério da Saúde, 2002.

STRALEN, Cornelis Johannes van et al. Percepção dos usuários e profissionais de saúde sobre atenção básica: comparação entre unidades com e sem saúde da família na Região CentroOeste do Brasil. Cadernos de Saúde Pública. Rio de Janeiro, v.24, Sup.1. p.S148- S158. 2008. Disponível em: $<$ http://regional.bvsalud.org $>$. Acesso em27 de outubro de 2015. 